\title{
Diabetes Developing Diagram
}

\author{
Nuredin Bakhtiari \\ Department of Biochemistry, Faculty of Basic Sciences, Young Researchers and Elite Club, Sanandaj Branch, \\ Islamic Azad University, Sanandaj, Iran \\ Email: nuredin.bakhtiary@modares.ac.ir
}

Received 15 April 2016; accepted 16 May 2016; published 20 May 2016

Copyright @ 2016 by author and Scientific Research Publishing Inc.

This work is licensed under the Creative Commons Attribution International License (CC BY).

http://creativecommons.org/licenses/by/4.0/

(c) (i) Open Access

\begin{abstract}
Diabetes mellitus is a metabolic disorder that the cells cannot uptake and use glucose as a source of energy. Many dysfunctions in mitochondria biogenesis/activity and some glycolysis enzymes in diabetic patients have been reported. The aim of this mini-review is to elucidate the cross-talk between signaling pathway which involved in developing of diabetes. Here, there are a related, documented reasons and evidences which investigate energy deficiency in this disease. It seems that a cascade of signaling such as transcription factors (MEF2, CREB, NFAT, P38, MAPK, AMPK) co-activators (PGC-1 $\alpha$ ) such as calcium ion, protein dependent calcium(CAMK, calcineurine) and $\mathrm{Na}^{+}-\mathrm{K}^{+}$pump have a main role in cell energy regulation. Any dysfunction in these factors can develop diabetes and here, $\mathrm{Na}^{+}-\mathrm{K}^{+}$pump is known as a start point of this diagram.
\end{abstract}

\section{Keywords}

Diabetes, $\mathrm{Na}^{+-} \mathrm{K}^{+}$Pump, PGC-1 $\alpha$, AMPK

\section{Introduction}

Step-by-step development of diabetic disorder proposed a schematic "Energy homeostasis diagram" and accordingly, we suggested that alteration in $\mathrm{Na}^{+}-\mathrm{K}^{+}$pump structure/function might cause further modification towards diabetics. Diabetes mellitus is a disorder that involve whole metabolism of body [1], glucose uptake strength is low in diabetic patients [2]. In these individuals' energy charges, ATP/ADP is imbalance opposed to normal individuals [3]. Individuals that taken diabetes might have disordered in signal transduction [4], mitochondrial dysfunction [5], imbalance in calcium level in cytoplasm [6] or dysfunction in membrane proteins such as $\mathrm{Na}^{+}-\mathrm{K}^{+}$pump [7]. The goal of this short-communication is to unveil the cross-talk between signaling which is involved in energy homeostasis and finds the initiate point of this pathway as well as citric acid cycle which determines oxaloacetate as a critical point of cycle. There are some evidences that identify $\mathrm{Na}^{+}-\mathrm{K}^{+}$pump as a source of this impairment [8]. It is suggested that compensation of $\mathrm{Na}^{+}-\mathrm{K}^{+}$pump activity in diabetic patients might improve illness status through increasing of calcium level in cytoplasm [9]; activating of calcium signaling pathway proteins such as calmudulin-dependent kinase (CAMK) and calcineurine (a protein phosphates) [10] 
and these factors cause MEF2 (myocyte enhancer factor 2), NFAT (nuclear factor T-cell) activation [11] [12] which is accompanied by overexpression of PGC- $1 \alpha$ (peroxisome proliferators-activated receptor gamma coactivator-1 alpha) [13], then up-regulation of NRF-1(nuclear respiratory factor A) [14] and ultimately mitochondrial biogenesis has been observed [15]. On the other hand, concomitant collaboration between PGC-1 $\alpha$ with MEF2 leads to both up-regulation and transportation of GLUT4 (glucose transporter-4) toward cell membranes [16]. Furthermore, the interaction between PGC-1 $\alpha$ and PPAR (peroxisome proliferator activated receptor-Alpha) in turn modulates the expression of PPRES (PPAR Response elements) which lead to increase of enzymes overexpression which is involved in glucose and fatty acid oxidation [17]. In this so called schematic view, a reversible equilibrium among $\mathrm{Na}^{+}-\mathrm{K}^{+}$pump and mitochondrial biogenesis/activity is observed. In the absence of suitable function of this pump, the amount of $\mathrm{Na}^{+}$is overloaded in cytoplasm and this results in calcium penetration from mitochondria and also deficiency of calcium availability of cytoplasm. It should be pointed out that many calcium-dependent enzymes are working in mitochondria and decrease of matrix calcium has deleterious effects on them [18] [19]. On the other hand, harmful effects of lowering-calcium on intracellular energy production cause failure of $\mathrm{Na}^{+}-\mathrm{K}^{+}$pump. It should be noted that about $4 \%-50 \%$ of basal energy expenditure is used to maintain physiological intracellular sodium $\left(\mathrm{Na}^{+}\right)$and potassium $\left(\mathrm{K}^{+}\right)$concentrations [20]. Finally, we could found a series of related signals which cooperate altogether and result in cell energy homeostasis as it can be seen in Figure 1.

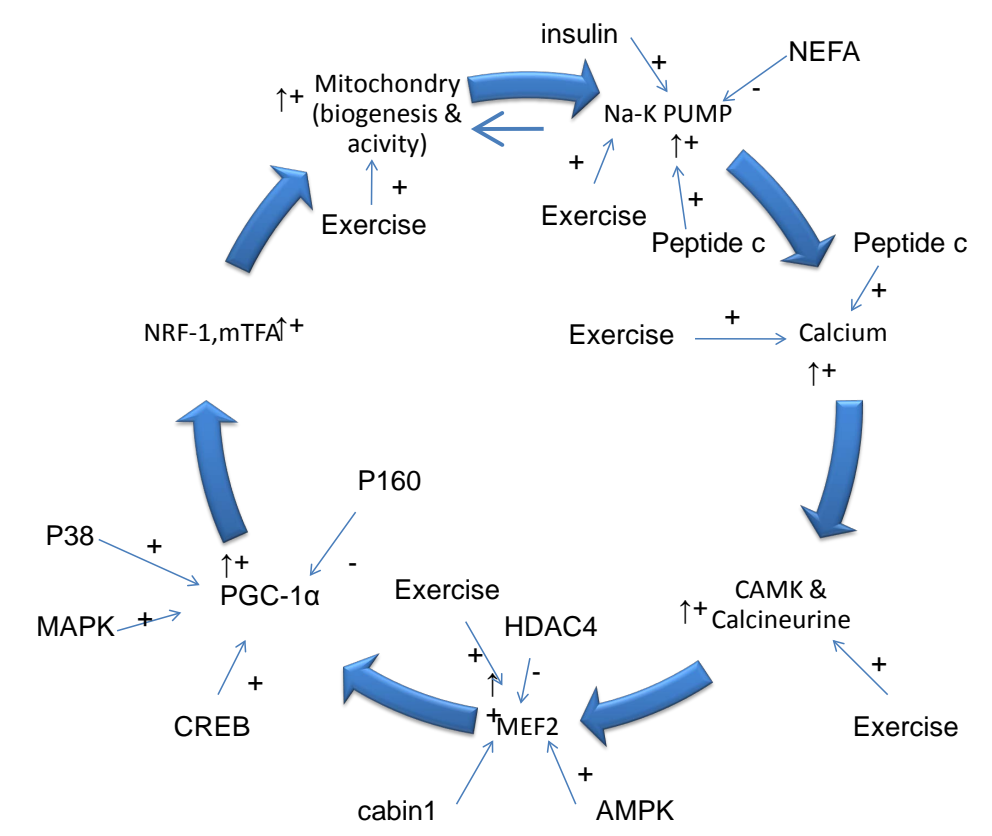

Figure 1. As it has been shown in the figure, there are some negative feedbacks such as NEFA (non-esterifies fatty acid), cabin1, HDACII and positive feedbacks like insulin, exercise, AMPK, P38, MAPK. According to the diagram the key point which can be considered as a starting and extending diabetes disease is disorder in $\mathrm{Na}^{+}-\mathrm{K}^{+}$Pump. As it has been shown ,the activators can increase intracellular level of calcium concentration (inhibitors can act inversely), at the second step, temporal and prolong increase in calcium concentration can led to activation of CAMK and calcineurin, protein-protein interaction between the mentioned proteins can activate a series of signals such as MEF2, NFAT which in turn leading to increase in PGC- $1 \alpha$ expression level, the role of the last factor is energy cell homeostasis and inducing NRF-1, NRF-2 activity/expression level. Also NRFs has a positive effect on nuclear genome which involved in expression of respiratory factors. Then, these factors will effect on mTFA (mithochondrial transcription factor), both factors can increase mitochondria biogenesis/activity. The backward arrow between Na-K pump and mitochondria at the top of figure reveals direct effect of increasing Na concentration on exiting Ca from mitochondria and inactivation of Ca-dependent mitochondorial enzymes. 


\section{Acknowledgements}

The author of this manuscript is so grateful from Young Researchers and Elite Club, Sanandaj Branch, Islamic Azad University, Sanandaj, Iran that financial support this study.

\section{Conflict and Interest}

We declare that there is not any conflict and interest from this study.

\section{References}

[1] Kelley, D.E., Mintun, M.A. and Watkins, S.C. (1996) The Effect of Non-Insulin-Dependent Diabetes Mellitus and Obesity on Glucose Transport and Phosphorylation in Skeletal Muscle. The Journal of Clinical Investigation, 97, 27052713. http://dx.doi.org/10.1172/JCI118724

[2] Beck-Nielsen, H., Vaag, A., Poulsen, P., et al. (2003) Metabolic and Genetic Influence on Glucose Metabolism in Type 2 Diabetic Subjects-Experiences from Relatives and Twin Studies. Best Practice \& Research Clinical Endocrinology \& Metabolism, 17, 445-467. http://dx.doi.org/10.1016/S1521-690X(03)00041-1

[3] Hojlund, K., Wrzesinski, K. and Larsen, P.M. (2003) Proteome Analysis Reveals Phosphorylation of ATP Synthase Beta-Subunit in Human Skeletal Muscle and Proteins with Potential Roles in Type 2 Diabetes. The Journal of Biological Chemistry, 278, 10436-10442. http://dx.doi.org/10.1074/jbc.M212881200

[4] Cho, H., Mu, J., Kim, J.K. and Thorvaldsen, J. (2001) Insulin Resistance and a Diabetes Mellitus-Like Syndrome in Mice Lacking the Protein Kinase Akt2 (PKB Beta). Science, 292, 1728-1731. http://dx.doi.org/10.1126/science.292.5522.1728

[5] Kelley, D.E., He, J., Menshikova, E.V. and Ritov, V.B. (2002) Dysfunction of Mitochondria in Human Skeletal Muscle in Type 2 Diabetes. Diabetes, 51, 2944-2950. http://dx.doi.org/10.2337/diabetes.51.10.2944

[6] Chin, E.R., Olson, E.N. and Richardson, J.A. (1998) A Calcineurin-Dependent Transcriptional Pathway Controls Skeletal Muscle Fiber Type. Genes \& Development, 12, 2499-2509. http://dx.doi.org/10.1101/gad.12.16.2499

[7] Kjeldsen, K., Braembgaard, H. And Sidenins, P. (1987) Diabetes Decreases $\mathrm{Na}^{+}-\mathrm{K}^{+}$Pump Concentration in Skeletal Muscles, Ventricular Muscle, and Peripheral Nerves of Rat. Diabetes, 36, 842-848. http://dx.doi.org/10.2337/diab.36.7.842

[8] Pierce, G.N. and Dhalla, N.S. (1983) Sarcolemmal Na'-K4-ATPase Activity in Diabetic Rat Heart. American Journal of Physiology, 245, C241-C247.

[9] Berchtold, M.W., Brinkmeier, H. and Müntener, M. (2000) Calcium Ion in Skeletal Muscle: Its Crucial Role for Muscle Function, Plasticity, and Disease. Physiological Reviews, 80, 1215-1265.

[10] Semsarian, C., Wu, M.J., Ju, Y.K., Marciniec, T. and Yeoh, T. (1999) Skeletal Muscle Hypertrophy Is Mediated by a Ca21-Dependent Calcineurin Signalling Pathway. Nature, 400, 576-581. http://dx.doi.org/10.1038/23054

[11] Serena Borghi, S. (2001) Ferrari the Nuclear Localization Domain of the MEF2 Family of Transcription Factors Shows Member-Specific Features and Mediates the Nuclear Import of Histone Deacetylase 4 Dipartimento di Scienze Biomediche, Sezione di Chimica Biologica, Università di Modena e Reggio Emilia, Via G. Campi 287, 41100 Modena, Italy. Journal of Cell Science, 114, 4477-4483.

[12] Youn, H.-D., Grozinger, C.M. and Liu, J.O. (2000) Calcium Regulates Transcriptional Repression of Myocyte Enhancer Factor 2 by Histone Deacetylase 4. The Journal of Biological Chemistry, 275, 22563-22567. http://dx.doi.org/10.1074/jbc.C000304200

[13] Liang, H.Y and Walter, F. (20006) Ward PGC-1 $\alpha$ : A Key Regulator of Energy Metabolism. Advances in Physiology Education, 30, 145-151. http://dx.doi.org/10.1152/advan.00052.2006

[14] Andersson, U. and Scarpulla, R.C. (2001) PGC-1-Related Coactivator, a Novel, Serum-Inducible Coactivator of Nuclear Respiratory Factor 1-Dependent Transcription in Mammalian. Cells Molecular and Cellular Biology, 11, 37383749.

[15] Lehman, J.J., Barger, P.M., Kovacs, A., Saffitz, J.E., Medeiros, D.M. and Kelly, D.P. (2000) Peroxisome ProliferatorActivated Receptor Gamma Coactivator-1 Promotes Cardiac Mitochondrial Biogenesis. Journal of Clinical Investigation, 106, 847-856. http://dx.doi.org/10.1172/JCI10268

[16] Michael, L.F., Wu, Z., Cheatham, R.B., Puigserver, P. and Adelmant, G. (2001) Restoration of Insulin-Sensitive Glucose Transporter (GLUT4) Gene Expression in Muscle Cells by the Transcriptional Coactivator PGC-1. Proc Natl Acad Sci USA, 98, 3820-3825. http://dx.doi.org/10.1073/pnas.061035098

[17] Puigserver, P. and Spiegelman, B.M. (2003) Peroxisome Proliferator-Activated Receptor- $\gamma$ Coactivator $1 \alpha$ (PGC-1 $\alpha$ ): Transcriptional Coactivator and Metabolic Regulator. Endocrine Reviews, 24, 78-90. 
http://dx.doi.org/10.1210/er.2002-0012

[18] Ramasamy, R. and Schaefer, S. (1999) Inhibition of $\mathrm{Na}^{+}-\mathrm{H}^{+}$Exchanger Protects Diabetic and Non-Diabetic Hearts from Ischemic Injury: Insight into Altered Susceptibility of Diabetic Hearts to Ischemic Injury. Journal of Molecular and Cellular Cardiology, 31, 785-797. http://dx.doi.org/10.1006/jmcc.1998.0908

[19] Doliba, N.M., Babsky, A.M., Wehrli, S.L., Doliba, N.M., Ivanics, T.M., Friedman, M.F. and Osbakken, M.D. (2000) Metabolic Control of Sodium Transport in Streptozotocin-Induced Diabetic Rat Heart. Biokhimia, 65, 502-508.

[20] Clausen, T., van Hardeveld, C. and Everts, M.E. (1991) Significance of Cation Transport in Control of Energy Metabolism and Thermogenesis. Physiological Reviews, 71, 733-774.

\section{Abbreviation}

MEF2 (myocyte enhancer factor 2), CREB (cAMP response elements), NFAT (nuclear factor of activated T-cells), MAPK (mitogen-activated protein kinases), AMPK (5' adenosine monophosphate-activated protein kinase), PGC- $1 \alpha$ (peroxisome proliferator-activated receptor gamma coactivator 1-alpha), CAMK $\left(\mathrm{Ca}^{2+} / \mathrm{calmo}^{-}\right.$ dulin-dependent protein kinase), Calcineurin (calcium and calmodulin dependent serine/threonine protein phosphatase), PPAR (peroxisome proliferator activated receptor-Alpha), GLUT4 (glucose transporter-4), NRF-1 (nuclear respiratory factor A), PPAR (peroxisome proliferator activated receptor-Alpha). 